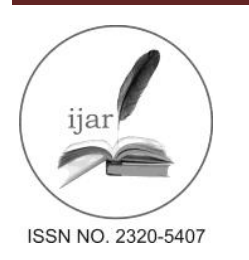

\author{
Journal homepage: http://www.journalijar.com \\ Journal DOI: 10.21474/IJAR01
}

RESEARCH ARTICLE

\title{
TEMPORAL DYNAMICS OF DEMERSAL FISHING PROFILES OF THE ARTISANAL FISHING FLEET SEGMENT ON THE PETITE CÔTE OF SENEGAL.
}

\author{
*Ismaïla Ndour, Ndiaga Thiam, Massal Fall, Hamet Diaw Diadhiou. \\ Institut Sénégalais de Recherche Agricole [ISRA]/Centre de Recherches Océanographiques de Dakar-Thiaroye \\ [CRODT], Pôle de Recherche de Hann, Dakar, Sénégal.
}

\section{Manuscript Info}

Manuscript History:

Received: 16 April 2016

Final Accepted: 26 May 2016

Published Online: June 2016

Key words:

Dynamics, Demersal species,

Fishing profiles, Artisanal fishing,

Senegal.

*Corresponding Author

Ismaïla Ndour.

\begin{abstract}
This work investigates the temporal dynamics of demersal fishing profiles of the artisanal fishing fleet segment off the Petite Côte of Senegal. Using a multivariate approach to examine commercial artisanal fishing data (provided by the Centre for Oceanographic Research of Dakar-Thiaroye [CRODT] in Senegal), the fishing profiles of this fishery were defined and their evolution through the time described in two landings sites (Joal and Mbour). The results showed in total 11 demersal fishing profiles based on gear category, landings site, year and the major captured species. Fishing profile changes were observed by years, mainly in connection with the target species. Significant variations on the main species caught were found between the periods 2004-2011 and 2012-2013 for the "“fixed net" category" and between the periods 2004-2005 and 2006-2013 for the "“longline" category" at Joal' site and for the "“various gears" group" at Mbour' site. The comparison of fishing profiles between the two landing sites showed that fishing profiles that dominate at Mbour' site were characterized by poorly diversified catches (mainly Cymbium spp and Murex spp) compared to those prevailing at Joal' site and for which their catches were highly diversified. Understanding the fishers' adaptation strategies to the scarcity of fishery resources ( $c f$. catch - fishing effort ratio) through their way of using the resource over time is of great interest for managers to adapt resource management measures to recent changes in the fishery.
\end{abstract}

Copy Right, IJAR, 2016...All rights reserved..

\section{Introduction:-}

As in most of the coastal West African countries, fishing plays an important socio-economic role in Senegal. It generates foreign exchange, creates jobs (15\% of the total Senegalese workforce) and it is the main source of animal protein $(75 \%)$ in the diet of the Senegalese population (Kébé, 2008). These economic and social assets of fisheries in Senegal are the result of the dynamic sub-sector of artisanal fisheries, which provides about $90 \%$ of landings and contributes nearly $60 \%$ of the quantities of exported products (ANDS, 2011). However, this sub-sector is today subject to various mutations.

The scarcity of fishery resources requires artisanal fishers from Senegal to change their behaviour in their fishing activities and fishing operations (Ndour et al., 2014). This adaptation may change the pattern of artisanal fishing formerly known through different previous studies (Laloë and Samba, 1990; Ferraris and Samba, 1992; Fall et al., 2006). In this context, it presents a new challenge, which is to understand how these changes are reflected on fishing operations by referring to the fishing gear categories used, to the landings sites and to the targeted species (Fall et al., 2006; Maynou et al., 2003, 2011; Leleu et al., 2014). The layout of these kinds of information is fundamental for 
scientists and managers to adapt fisheries management measures to recent changes in the fishery in favour of a more rational and sustainable management model of fisheries resources (Fluharty, 2011).

This paper aims to determine and analyze the temporal dynamics of demersal fishing profiles of the artisanal fleet segment at the Petite Côte of Senegal and compare them with previous results obtained through studies on tactics and fishing typologies (Bousso, 1994; Fall et al., 2006), in order to detect changes in the fishery in a context of overexploitation.

\section{Materials and Methods:-}

Data sources:-

Artisanal commercial fishing was obtained from the Centre for Oceanographic Research of Dakar-Thiaroye (CRODT) in Senegal. The catches per species were assessed based on daily surveys of landings at the localities of Mbour and Joal on the Southern coast (Petite Côte) of Senegal (Figure 1) between 2004 and 2013. The choice of Mbour and Joal was related to the fact that they were the two most important fishing harbours on the Southern coast of Senegal (Petite Côte) in terms of artisanal fishing landings (82\% (CRODT, 2012)). The collection method was based on a hierarchical three-tier stratification scheme on: (i) the fishing port; (ii) the fifteen days during which fishing occurred; and (iii) the type of gear used. The choice of fifteen days as basic time unit help to avoid missing data that may result from lack of fishing trip in a day (case of choosing the day as unit) for festive reasons, weather conditions etc. This method incorporated the spatio-temporal variations of each fishing method. The catch was extrapolated according to the following equations (Modified from Ferraris and Samba 1992).

$$
F f_{i j}=\sum_{d=1}^{15} F d_{i j}
$$

Where $F f$ is the fishing effort (fishing trip) in the fifteen days; $F d$ is the fishing effort in the day $d$ for fishing gear $i$ and port $j$.

$$
C f_{i j}=\left[\frac{C s d}{F s d}\right]_{i j} * F f_{i j}
$$

Where $C f$ is the catch in the fifteen days; $C s d$ is the catch in the surveyed days in the fifteen days; $F s d$ is the fishing effort (fishing trip) in the surveyed days in the fifteen days; and $F f$ is the fishing effort in the fifteen days for fishing gear $i$ and port $j$.

$$
C a_{i j}=\sum_{f=1}^{24}\left(C f_{i j}\right)
$$

Where $C a$ is the annual catch; $C f$ is the catch in the fifteen days and 24 is the number of fifteen days in the year. 


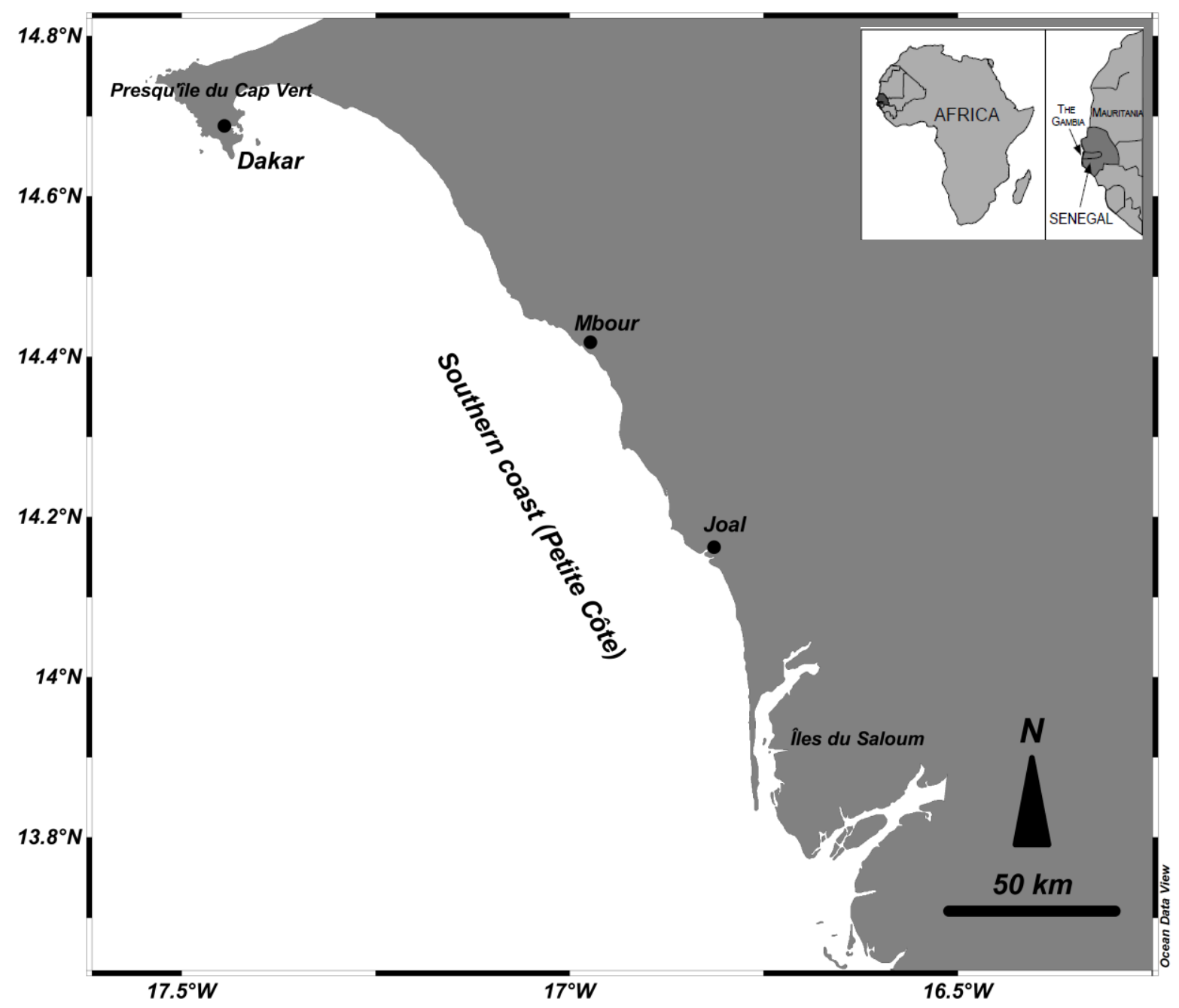

Figure 1:- Map showing the study area with the landings sites of Joal and Mbour along the Southern coast (Petite Côte) of Senegal.

\section{Data treatment:-}

A multivariate approach was followed to determine the fishing profiles of the demersal artisanal fleet segment, using the catch volumes (tons). The data set was transformed into a matrix with rows denoting year $\times$ gear category and columns denoting species. The list of species retained was composed of 22 species, which comprised $94.4 \%$ of the catch (tons) of the demersal artisanal fleet segment in the two landings sites in the study period.

Thereafter, a Hierarchical Cluster Analysis (HCA, using Euclidean distance and Ward's aggregation method (Pelletier and Ferraris, 2000)), a Correspondence Analysis (CA) and a Principal Component Analysis (PCA) centred, reduced were applied to the data matrix. All analyses were carried out with the R software environment for statistical computing, using the stats library R-ADE 4 (Thioulouse and Dray, 2007).

The data used in the analysis of dynamics of demersal fishing profiles of the artisanal fishing included catch by species, fishing effort and fishing gear (Table 1). As the catch varied significantly from one fishing gear to another and between years and between landings sites both in terms of species composition and quantity ( $<<0.05$, One-way ANOVA (Table 2)), the catch of each species were aggregated by gear category on an annual scale for each landings site for getting the catch by gear category. 
Table 1:- Catch (tons) and effort (fishing trip) by gear groups of artisanal fisheries at two fishing harbours (Joal and Mbour) on the Southern coast (Petite Côte) of Senegal from 2004 to 2013.

\begin{tabular}{|c|c|c|c|c|c|c|c|c|c|c|c|}
\hline & Year & $\begin{array}{l}\text { Effort/Cat } \\
\text { ch }\end{array}$ & $\begin{array}{c}\text { Fixed } \\
\text { net }\end{array}$ & $\begin{array}{c}\text { Diverse } \\
\text { lines }\end{array}$ & Longline & $\begin{array}{l}\begin{array}{l}\text { Purse } \\
\text { seine }\end{array} \\
\end{array}$ & $\begin{array}{l}\text { Simpl } \\
\text { e line }\end{array}$ & $\begin{array}{c}\text { Various } \\
\text { gears }\end{array}$ & $\begin{array}{c}\text { Encircling } \\
\text { gillnet }\end{array}$ & $\begin{array}{c}\text { Beach } \\
\text { seine }\end{array}$ & Total \\
\hline \multirow[t]{20}{*}{ Joal } & \multirow[t]{2}{*}{2004} & Fishing trip & 15839 & 15906 & 974 & 9611 & - & 8 & 1127 & 818 & 44283 \\
\hline & & Catch (t) & 7724 & 1944 & 1502 & 478 & - & 0 & 5 & 36 & 11689 \\
\hline & \multirow[t]{2}{*}{2005} & Fishing trip & 16183 & 12920 & 2665 & 10256 & 1 & 2 & 3637 & 881 & 46546 \\
\hline & & Catch $(\mathrm{t})$ & 9809 & 1424 & 6214 & 289 & 0 & 0 & 0 & 136 & 17872 \\
\hline & \multirow[t]{2}{*}{2006} & Fishing trip & 15768 & 14790 & 2218 & 9708 & - & - & 1315 & - & 43799 \\
\hline & & Catch (t) & 4461 & 1496 & 3137 & 593 & - & - & 2 & - & 9689 \\
\hline & \multirow[t]{2}{*}{2007} & Fishing trip & 17098 & 11453 & 866 & 14225 & - & - & 2497 & - & 46139 \\
\hline & & Catch $(\mathrm{t})$ & 4415 & 1084 & 1550 & 352 & - & - & 7 & - & 7408 \\
\hline & \multirow[t]{2}{*}{2008} & Fishing trip & 22603 & 11136 & 318 & 11812 & - & - & 2239 & - & 48108 \\
\hline & & Catch $(\mathrm{t})$ & 5572 & 1058 & 76 & 278 & - & - & 7 & - & 6991 \\
\hline & \multirow[t]{2}{*}{2009} & Fishing trip & 18569 & 9636 & 147 & 12198 & - & 2 & 2552 & - & 43103 \\
\hline & & Catch (t) & 3580 & 708 & 183 & 668 & - & 0 & 2 & - & 5141 \\
\hline & \multirow[t]{2}{*}{2010} & Fishing trip & 14376 & 11926 & 10 & 14310 & - & - & 1159 & - & 41782 \\
\hline & & Catch (t) & 2126 & 1170 & 14 & 501 & - & - & 35 & - & 3846 \\
\hline & \multirow[t]{2}{*}{2011} & Fishing trip & 15721 & 13370 & 2 & 12490 & - & - & - & - & 41583 \\
\hline & & Catch (t) & 3975 & 1779 & 4 & 489 & - & - & - & - & 6247 \\
\hline & \multirow[t]{2}{*}{2012} & Fishing trip & 22769 & 12302 & 1492 & 19952 & - & - & - & - & 56515 \\
\hline & & Catch (t) & 26854 & 2094 & 5632 & 759 & - & - & - & - & 35339 \\
\hline & \multirow[t]{2}{*}{2013} & Fishing trip & 20042 & 9557 & 520 & 14549 & 354 & - & 6680 & 3 & 51705 \\
\hline & & Catch (t) & 30701 & 1172 & 2296 & 732 & 95 & - & 57 & 1 & 35054 \\
\hline \multirow{20}{*}{$\begin{array}{l}\text { Mbo } \\
\text { ur }\end{array}$} & \multirow[t]{2}{*}{2004} & Fishing trip & 21545 & 28411 & 6156 & 2478 & 3681 & 1808 & - & - & 64080 \\
\hline & & Catch (t) & 3608 & 2623 & 2462 & 36 & 1161 & 268 & - & - & 10158 \\
\hline & \multirow[t]{2}{*}{2005} & Fishing trip & 27947 & 24280 & 8606 & 5879 & 5409 & 1916 & - & - & 74038 \\
\hline & & Catch (t) & 5804 & 2391 & 2468 & 45 & 54 & 254 & - & - & 11016 \\
\hline & \multirow[t]{2}{*}{2006} & Fishing trip & 22418 & 16830 & 8447 & 2340 & 3594 & 1414 & - & - & 55043 \\
\hline & & Catch $(\mathrm{t})$ & 3427 & 1422 & 1734 & 42 & 21 & 129 & - & - & 6775 \\
\hline & \multirow[t]{2}{*}{2007} & Fishing trip & 19879 & 16713 & 6213 & 3681 & 4841 & 1834 & - & - & 53161 \\
\hline & & Catch (t) & 2991 & 2201 & 1995 & 20 & 37 & 243 & - & - & 7487 \\
\hline & \multirow[t]{2}{*}{2008} & Fishing trip & 17988 & 17343 & 8434 & 3103 & 5698 & 2454 & - & - & 55020 \\
\hline & & Catch $(\mathrm{t})$ & 2985 & 2638 & 3055 & 13 & 54 & 934 & - & - & 9679 \\
\hline & \multirow[t]{2}{*}{2009} & Fishing trip & 20572 & 18769 & 7408 & 2897 & 3593 & 2854 & 26 & - & 56118 \\
\hline & & Catch $(\mathrm{t})$ & 3813 & 1845 & 2479 & 109 & 31 & 645 & 0 & - & 8922 \\
\hline & \multirow[t]{2}{*}{2010} & Fishing trip & 16963 & 16369 & 6895 & 2659 & 2416 & 3346 & - & - & 48648 \\
\hline & & Catch (t) & 2577 & 1969 & 3021 & 16 & 30 & 741 & - & - & 8354 \\
\hline & \multirow[t]{2}{*}{2011} & Fishing trip & 17980 & 21109 & 7138 & 3748 & 1626 & 2901 & - & - & 54502 \\
\hline & & Catch (t) & 2727 & 2913 & 2979 & 94 & 21 & 589 & - & - & 9323 \\
\hline & \multirow[t]{2}{*}{2012} & Fishing trip & 15096 & 20420 & 7519 & 6979 & 1183 & 2601 & - & - & $\mathbf{5 3 7 9 8}$ \\
\hline & & Catch $(\mathrm{t})$ & 2297 & 6364 & 8594 & 98 & 27 & 390 & - & - & 17770 \\
\hline & \multirow{2}{*}{2013} & Fishing trip & 15609 & 16426 & 8633 & 2877 & 2096 & 2590 & - & - & 48232 \\
\hline & & Catch (t) & 1965 & 2100 & 3767 & 74 & 11 & 327 & - & - & 8244 \\
\hline
\end{tabular}


Table 2:- Statistical analysis of the effects of landings site, year and gear category on catch (tons), using a One-way ANOVA test, ns: no significant (error probability $\mathrm{p}>0.05)$, *: significant $(\mathrm{p}<0.05)$, **: highly significant ( $\mathrm{p}<$ $0.01)$ and $* * *$ : very highly significant $(\mathrm{p}<0.001)$.

\begin{tabular}{|c|c|c|c|c|c|c|}
\hline & Df & Sum Sq & Mean Sq & F value & $\mathrm{p}$ & \\
\hline Landings site & 1 & 399700 & 399700 & 165.182 & $<2 \mathrm{e}-16$ & $* * *$ \\
\hline Year & 9 & 286625 & 286625 & 118.452 & $<2 \mathrm{e}-16$ & $* * *$ \\
\hline Gear category & 7 & 1006141 & 143734 & 59.4 & $<2 \mathrm{e}-16$ & $* * *$ \\
\hline Residuals & 20189 & 48852462 & 2420 & & & \\
\hline
\end{tabular}

\section{Results:-}

\section{Hierarchical cluster analysis:-}

Based on gear categories, landings sites, years and the mainly captured species relationships, in general, multivariate analyses indicated the formation of three to four fishing profile groups (Figure 2A-2F), depending on the geographic area and on the considered variable. There were four main groups of gear categories ("fixed net", "diverse lines", "longline", "various gears") for Joal and Mbour, three and four main groups of years for respectively Joal (20042005, 2006-2011 and 2012-2013) and Mbour (2004-2005, 2006-2009, 2012 and 2010-2011-2013) and four and three main groups of species for Joal and Mbour, respectively. 

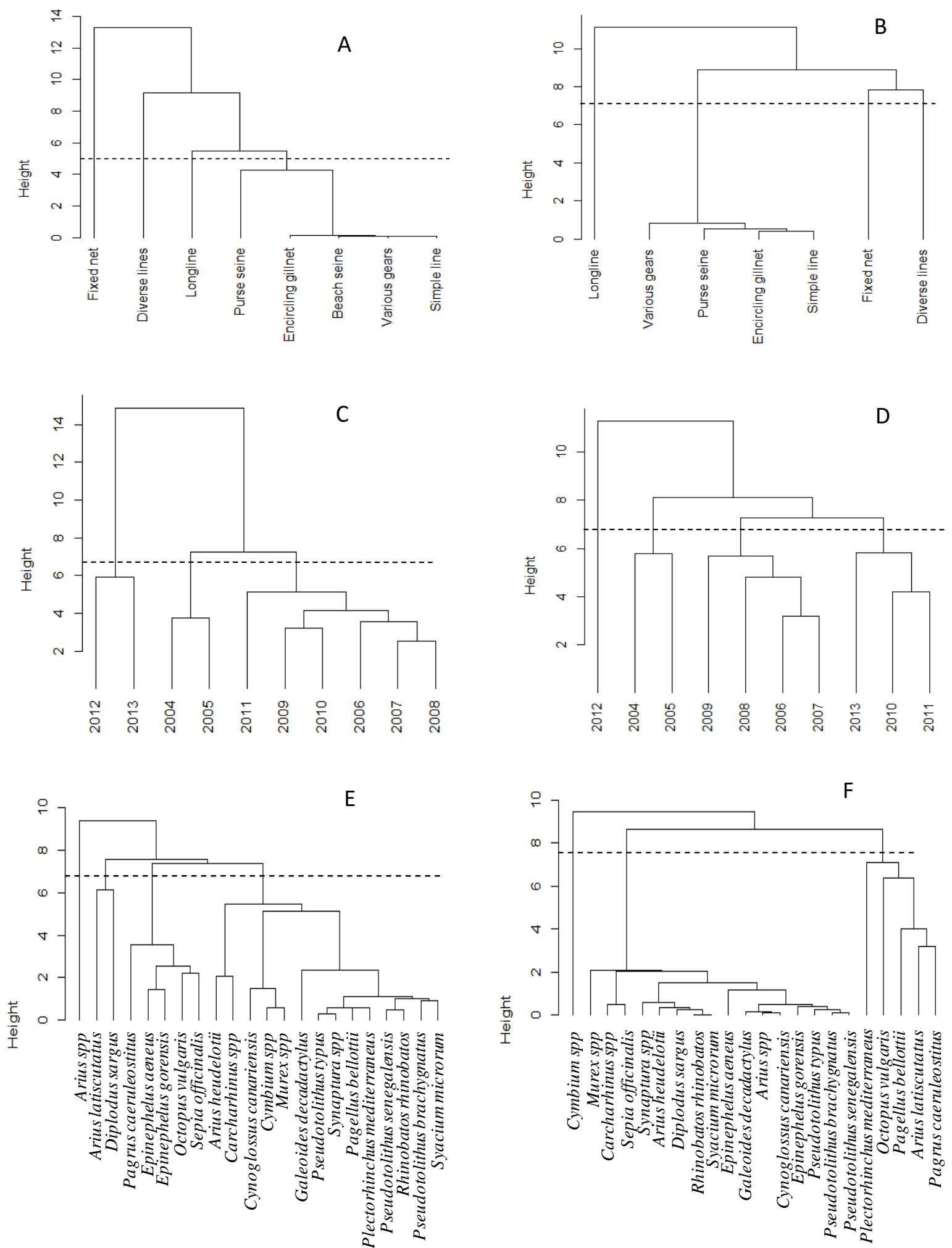

Figure 2:- Hierarchical clustering by landings site: Joal (left) and Mbour (right). Dendrograms of the cluster classification of the fishing gear category $(A, B)$; the year of fishing $(C, D)$ and the species composition $(E, F)$ in terms of $\%$ catch. 


\section{Correspondence analysis:-}

The Correspondence Analysis at Joal' site showed relationships between gear category and species groups caught in different time periods (Figure 3). The axes of the Factorial Correspondence Analysis (FCA) explained 55.00\% of the total variability which $29.96 \%$ for axis 1 and $25.04 \%$ for axis 2. Most of catches of Murex sp (Gastropod), Cymbium spp (Gastropod) and Pseudotolithus senegalensis (Demersal fish) during the period from 2004 to 2011 was from the "fixed net". Galeoides decadactylus, P. brachygnathus, P. typus, Diplodus sargus, Arius spp, A. heudelotii and Plectorhinchus mediterraneus (Demersal fish) were the most caught species by the ""various gears" category" during the period 2004 to 2013. "The "diverse lines" category" landings were dominated by Octopus vulgaris (Cephalopod), Sepia officinalis (Cephalopod), Epinephelus aeneus, E. gorensis, Pagellus bellottii, Pagrus caeruleostictus and Rhinobatos rhinobatos (Demersal fish) during the study period. Some temporal variations were observed on "fixed net" and "longline" groups. In the period 2012 to 2013, Syacium micrurum (Demersal fish) was the main founded species in the catch of the "fixed net". As to "longline", dominant species from 2006 to 2013 were Arius latiscutatus and Cynoglossus canariensis (Demersal fish), while they were P. mediterraneus, A. heudelotii and P. typus (Demersal fish) from 2004 to 2005.

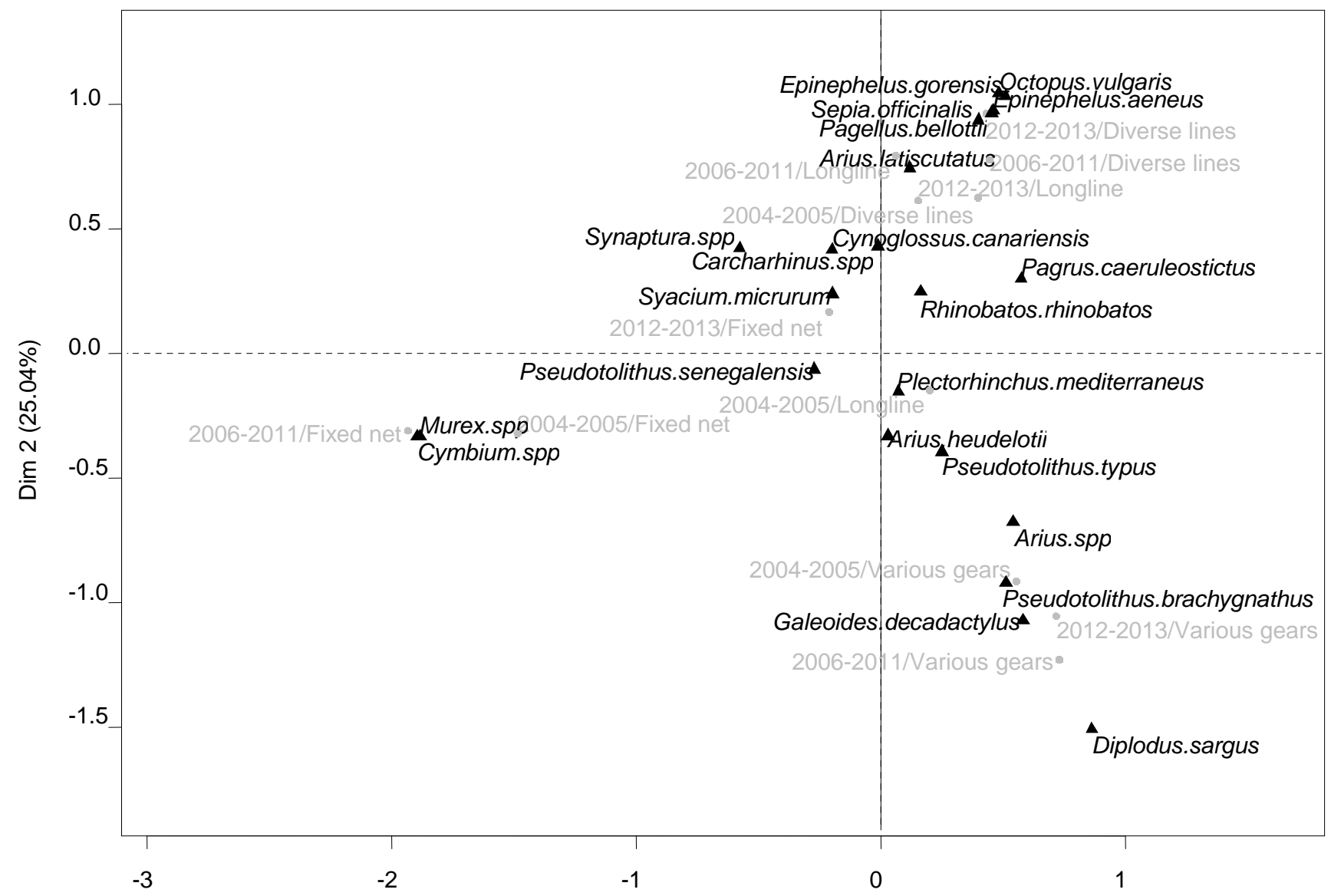

$\operatorname{Dim} 1(29.96 \%)$

Figure 3:- Factorial Correspondence Analysis (FCA) relating the fishing year x gear category (in gray) established for the artisanal fishing fleet segment at Joal' site to species composition (in black).

The CA at Mbour' site showed relationships between gear category and species groups caught in different time periods (Figure 4). The axes of the FCA explained $63.96 \%$ of the total variability which $41.58 \%$ for axis 1 and $22.38 \%$ for axis 2. For the "fixed net" Murex sp, Cymbium spp (Gastropods) and Synaptura spp (Demersal fish) were dominant from 2004 to 2013. As to ““diverse lines” category”, Sepia officinalis (Cephalopod), Arius heudelotii, Carcharhinus spp and Pagrus caeruleostictus (Demersal fish) were the most represented species in their 
catches during the study period except 2012, where Octopus vulgaris (Cephalopod) was dominant. From 2004 to 2005 most of catches of Syacium micrurum, Rhinobatos rhinobatos and Diplodus sargus (Demersal fish) was from "the "various gears" category". In contrast from 2006 to 2013, the main species founded in the catch were $P$. mediterraneus (Demersal fish) and Cymbium spp (Gastropod). As to "“Longline" category", landings mainly consisted of A. latiscutatus, E. gorensis, E. aeneus, P. bellottii, P. brachygnathus, P. typus and Arius spp (Demersal fish) during the study period except 2012, where Galeoides decadactylus, C. canariensis and P. senegalensis (Demersal fish) were dominant.

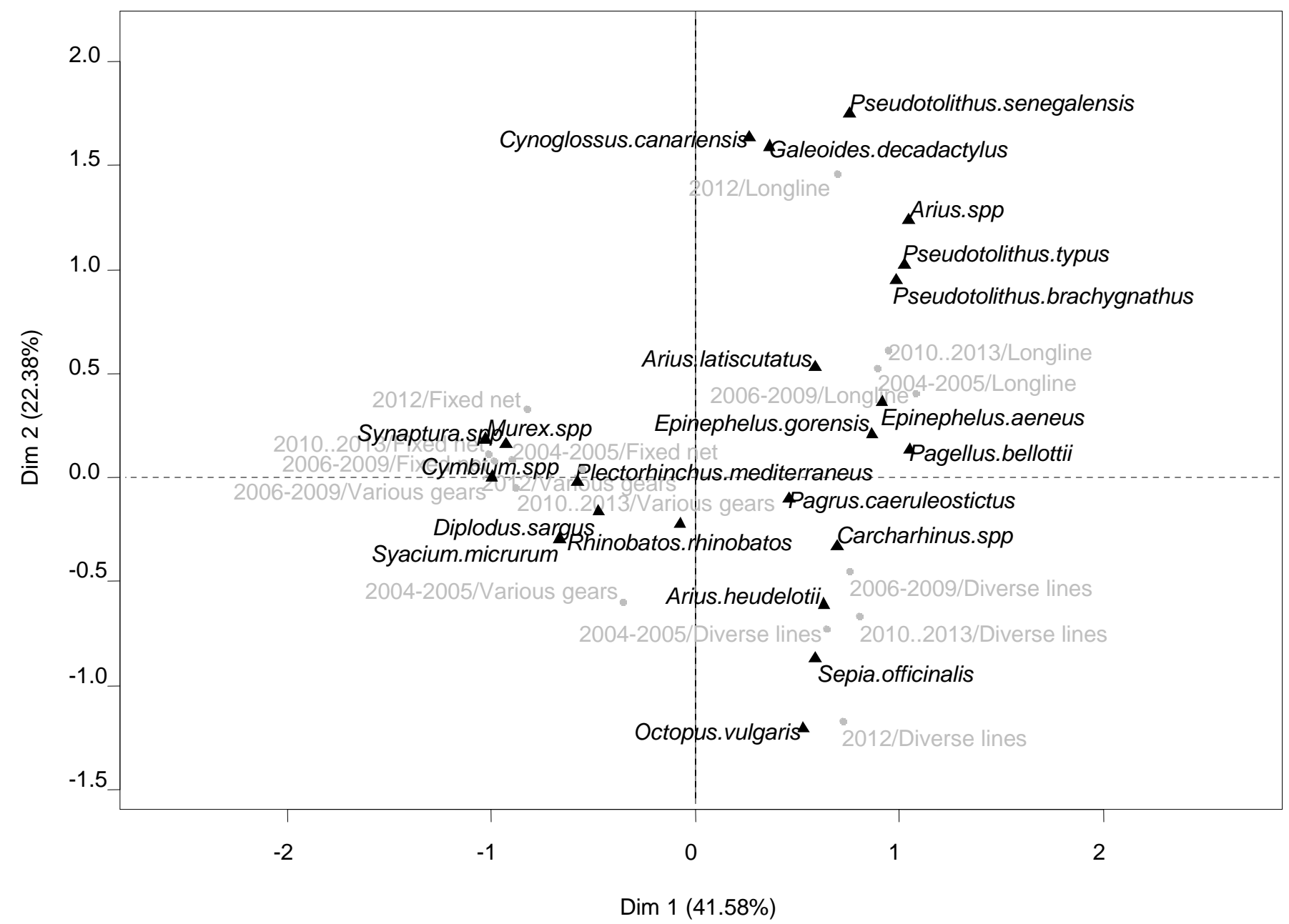

Figure 4:- Factorial Correspondence Analysis (FCA) relating the fishing year x gear category (in gray) established for the artisanal fishing fleet segment at Mbour' site to species composition (in black).

Fishing profiles determination:-

Based on gear categories, landings sites, years and the mainly captured species, in total 11 demersal fishing profiles were determined, 6 at Joal' site and 5 at Mbour' site (Table 3). 
Table 3:- Demersal fishing profiles determined, based on gear category, landings site, year and the major species captured in two fishing harbours off the Petite Côte of Senegal from 2004 to 2013.

\begin{tabular}{|c|c|c|c|c|}
\hline $\begin{array}{l}\text { Fishing } \\
\text { profiles }\end{array}$ & $\begin{array}{l}\text { Gear } \\
\text { category }\end{array}$ & $\begin{array}{l}\text { Landings } \\
\text { site }\end{array}$ & Years & Species \\
\hline Profile 1 & Fixed net & Joal & $\begin{array}{l}\text { from } 2004 \text { to } \\
2011\end{array}$ & Murex spp, Cymbium spp and Pseudotolithus senegalensis \\
\hline Profile 2 & \begin{tabular}{|l|} 
Various \\
gears
\end{tabular} & Joal & $\begin{array}{l}\text { from } 2004 \text { to } \\
2013\end{array}$ & $\begin{array}{l}\text { Galeoides decadactylus, P. brachygnathus, P. typus, } \\
\text { Diplodus sargus, Arius spp, A. heudelotii and } \\
\text { Plectorhinchus mediterraneus }\end{array}$ \\
\hline Profile 3 & $\begin{array}{l}\text { Diverse } \\
\text { lines }\end{array}$ & Joal & $\begin{array}{l}\text { from } 2004 \text { to } \\
2013\end{array}$ & $\begin{array}{l}\text { Octopus vulgaris, Sepia officinalis, Epinephelus aeneus, E. } \\
\text { gorensis, Pagellus bellottii, Pagrus caeruleostictus and } \\
\text { Rhinobatos rhinobatos }\end{array}$ \\
\hline Profile 4 & Fixed net & Joal & $\begin{array}{l}\text { from } 2012 \text { to } \\
2013\end{array}$ & Syacium micrurum \\
\hline Profile 5 & Longline & Joal & $\begin{array}{l}\text { from } 2004 \text { to } \\
2005\end{array}$ & $\begin{array}{l}\text { P. mediterraneus, A. heudelotii and } \\
\text { P. typus }\end{array}$ \\
\hline Profile 6 & Longline & Joal & $\begin{array}{l}\text { from } 2006 \text { to } \\
2013\end{array}$ & Arius latiscutatus and Cynoglossus canariensis \\
\hline Profile 7 & Fixed net & Mbour & $\begin{array}{l}\text { from } 2004 \text { to } \\
2013\end{array}$ & $\begin{array}{l}\text { Murex spp, Cymbium spp and } \\
\text { Synaptura spp }\end{array}$ \\
\hline Profile 8 & $\begin{array}{l}\text { Diverse } \\
\text { lines }\end{array}$ & Mbour & $\begin{array}{l}\text { from } 2004 \text { to } \\
2011 \text { and } \\
2013\end{array}$ & $\begin{array}{l}\text { Sepia officinalis, Arius heudelotii, Carcharhinus spp and } \\
\text { Pagrus caeruleostictus }\end{array}$ \\
\hline Profile 8 & $\begin{array}{l}\text { Diverse } \\
\text { lines }\end{array}$ & Mbour & 2012 & Octopus vulgaris \\
\hline Profile 9 & $\begin{array}{l}\text { Various } \\
\text { gears }\end{array}$ & Mbour & $\begin{array}{l}\text { from } 2004 \text { to } \\
2005\end{array}$ & $\begin{array}{l}\text { Syacium micrurum, Rhinobatos rhinobatos and Diplodus } \\
\text { sargus }\end{array}$ \\
\hline Profile 10 & \begin{tabular}{|l|} 
Various \\
gears
\end{tabular} & Mbour & $\begin{array}{l}\text { from } 2006 \text { to } \\
2013\end{array}$ & P. mediterraneus and Cymbium spp \\
\hline Profile 11 & Longline & Mbour & $\begin{array}{l}\text { from } 2004 \text { to } \\
2011 \text { and } \\
2013\end{array}$ & $\begin{array}{l}\text { A. latiscutatus, E. gorensis, E. aeneus, P. bellottii, } P \text {. } \\
\text { brachygnathus, P. typus and Arius spp }\end{array}$ \\
\hline Profile 11 & Longline & Mbour & 2012 & $\begin{array}{l}\text { Galeoides decadactylus, C. canariensis and } P . \\
\text { senegalensis }\end{array}$ \\
\hline
\end{tabular}

Temporal dynamic of fishing profiles:-

At Joal' site, variations were observed on "“fixed net" and "longline" groups" at temporal scale. In fact, from 2004 to 2005, Murex sp, Cymbium spp (Gastropods) and Pseudotolithus senegalensis (Demersal fish) were the most caught species by the "fixed net". In contrast, from 2012 to 2013, Syacium micrurum (Demersal fish) was dominant. As to the "longline" catches, they essentially consisted of Arius latiscutatus and Cynoglossus canariensis (Demersal fish) from 2006 to 2013, while P. mediterraneus, A. heudelotii and P. typus (Demersal fish) were the most abundant species in the catch from 2004 to 2005.

At Mbour' site, a temporal variation in catches of “"various gears" group” was observed. From 2004 to 2005 most of landings of Syacium micrurum, Rhinobatos rhinobatos and Diplodus sargus (Demersal fish) were from “" "various gears" category". In contrast, from 2006 to 2013, their catches were dominated by P. mediterraneus (Demersal fish) and Cymbium spp (Gastropod).

Changes of fishing profiles between landings site:-

The two first axes of the PCA centred, reduced explained $40.31 \%$ of the total variability which $24.45 \%$ for axis 1 and $15.86 \%$ for axis 2 (Figure 5A, 5B, 5C). Axis 1 separated a group characterized by highly diversified catches from another group corresponding to poorly diversified catches. Catches were more diversified with a low 
dominance at Joal' site than at Mbour' site, where dominance was high (Cymbium spp and Murex spp (Gastropods) and catches poorly diversified (Figure 5A, 5B, 5C). Axis 2 separated the categories of dominant gear at Mbour' site from those prevailing at Joal' site.

Significant changes of fishing profile were observed between Joal and Mbour sites. "fixed net" and "longline" were mainly associated to Joal' site, where, these gear categories targeted mainly Arius heudelotii, Cynoglossus canariensis (Demersal fish), Murex spp (Gastropod), Pseudotolithus typus, P. senegalensis, P. brachygnathus, Syacium micrurum, Rhinobatos rhinobatos, Diplodus sargus, Synaptura spp, Carcharhinus spp, Arius spp and Galeoides decadactylus (Demersal fish). In contrast, At Mbour' site, ““diverse lines" and "various gears" groups" were dominant and targeted mainly Octopus vulgaris (Cepalopod), P. mediterraneus, P. caeruleostictus (Demersal fish), Sepia officinalis (Cepalopod), E. aeneus and E. gorensis (Demersal fish) (Figure 5A, 5B, 5C).

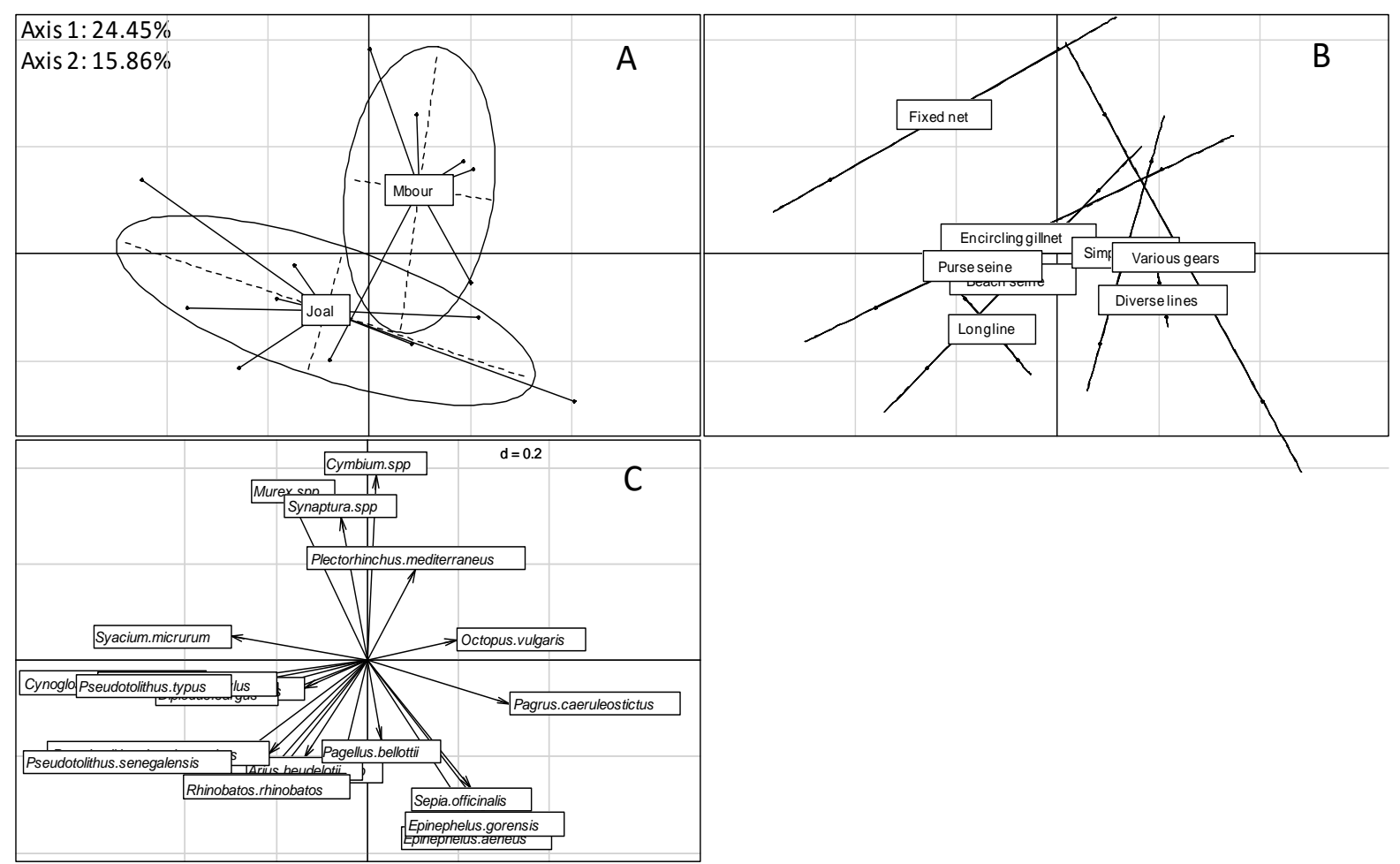

Figure 5:- Principal Component Analysis (PCA) relating associations of landings site (A) to the fishing gear category (B) and to species composition (C) for the artisanal fishing fleet segment in the Southern coast (Petite Côte) of Senegal.

\section{Discussion:-}

\section{Temporal dynamic:-}

The temporal change of the composition catches by "longline" and "various gears" was primarily explained by an abundance of exploited species associated with moderate fishing effort. Thereafter, the fishing effort increased causing a reduction in fishing yields. Lower yields having reached a critical level; fishers have adopted other fishing strategies mainly including the exploration of other fishing grounds off the Senegalese EEZ (Gambia, Guinea Bissau and Guinea). This practice was favoured by fishing agreements between Senegal and those countries especially in 2012 (fisheries agreement for 12 months). As to "fixed net", due to the emergence of Murex spp in the 2000s, fishers using this type of fishing had reoriented their target to this species in addition to regular catches of Cymbium spp. This fact is recurrent in artisanal fisheries. According to Forcada et al. (2010) fishers rotate fishing tactics throughout the year to optimize yields by targeting specific species. Thus, the fishing profiles change is regulated by resource distribution and availability of species (Leleu et al., 2014); hence the new change in the composition of the catches of this category of fishing gear from 2012 to 2013 with the dominance of Syacium micrurum.

\section{Changes of fishing profiles between landings site:-}


Most diversified catches at Joal than at Mbour' site can be explained by the nature of fishing gears that dominate in this area ("longline" and "fixed net"). In fact, the "fixed net" had low selectivity, because it is mainly through their spontaneous movements that the fish meet the net and captured therein (Charles-Dominique, 2003). As to "longline", besides the fact that fishers using this type of gear most often operated off or even in areas outside of the Senegalese EEZ (which increases the number of species in catches), it can be easily readapted for capturing different species depending on their availability (Jabeur et al., 2000; Leleu et al., 2014). However, the "diverse lines" and "various gears" that were more present at Mbour' site had a high selectivity and targeting mainly Octopus vulgaris and Sepia officinalis, hence the proportions of these species in their catch.

\section{Existing management in light of the study's outcomes:-}

In the West African countries, artisanal fisheries management is generally based on a single species model with measures relating to the determination of allowable catches (TACs); the allocation of specific fishing licenses, application of biological recovery by species, the prohibition of certain fishing gear or types of mesh. However, this management model has limits in the context of a very dynamic artisanal fishing; because it is often noted a transfer of fishing effort on other species to bypass these types of measures or rehabilitation of fishing gear so they have almost the same properties as those prohibited by the legislation.

\section{How might these results contribute to the management of the fishery?}

By determining fishing profiles in artisanal fishing for demersal species (link between fishing techniques developed strategies - caught species - used areas etc.) and providing a better view of the strategies developed (migration, combination of gear, transfer of fishing effort) and changes in fishing units (length of nets and canoes, motor power etc.), this study provides fisheries managers, the elements required to propose adaptive management measures based on a 'multiparametric prototype', which simultaneously integrate all these parameters and the result of their interactions. In the works of Bousso (1994), considering that the fishing gear is not necessarily linked to a fishing technique and conversely, the fishing gear was privileged rather than the fishing method and the elements that had been taken into account in the structure of the fishing unit were the fishing gear, the boat, the movement means and the crew. However, the approach in this study was more exhaustive because it favours the species caught, which therefore helps to understand how the priorities and expertise of the fisherman, environmental constraints and resource status or behaviour of the species are integrated into the operating system developed by the fisherman. The originality of this approach also lies in the fact that a fishing profile will no longer be assigned to a single gear but rather a category of fishing gear which has the same species catches properties. This result is of great interest to managers for defining a fishing unit adapted to the current context of the fishery. This work on artisanal fishing complements the work of Fall et al. (2006) on industrial fishing, who had to use the same approach.

\section{Specific recommendations:-}

This work represents an improvement over the level of exploratory analyses that are typically undertaken in developing nations, particularly in West Africa. Thereby, we recommend this approach for multi-species, multi-gear fisheries more generally. As recommendation to, it will be necessary (i) to set standards norms for each type of fishing gear and implement them through the development of a communication strategy with stakeholders and (ii) to submit a better fishing license option suited to a multi-species exploitation.

To do this, we have to take the following control measures: the regulation of fishing trips and allocation of fishing licenses through the development of a communication strategy with stakeholders; the monitoring of catches by the collection and analysis of landing data and the limitation of production and exports to reduce fishing pressure.

\section{Limits of the approach:-}

However this approach is relevant, it needs to be monitored and evaluated in the medium term to incorporate the changes which may occur over time in the identified fishing profiles. In the long term, the distinction of fishing profiles may become difficult in a context of a fishery characterized by increasing pressure on the resource and continuing scarcity of species, because the adaptive strategies developed by fishers, could lead to the possibility catch of a given species by different fishing gears.

\section{Conclusion:-}

Understanding the temporal dynamics of fishing profiles, may help to manage fisheries according to the use fishers make of the resource over time. Taking into account the fishermen decisions (target species, fishing gear and location at specific times of the year etc.) is essential when designing management initiatives in a multispecies 
fisheries context. This work is of great interest to managers for defining a fishing unit adapted to the current context of the fishery. However, this study being carried out particularly from landings, an indication of fishing locations would also be of great importance for a comprehensive analysis of the dynamics of fishing profiles and a better understanding of the different scenarios adaptation of fishers to the scarcity of the resource for their integration into management processes.

\section{Acknowledgments:-}

The authors would like to thank Dr François Le Loc'h (IRD/LEMAR) for having read and corrected the manuscript; Dr Djiga Thiao (ISRA/CRODT); Dr Alassane Samba (Fisheries scientist consultant); Dr Justin Kantoussan (Gaston Berger University) for their scientific assistance and also Dr Amina Berraho and Dr Jamila Larissi (INRH of Casablanca) for their help in using Ocean Data View for mapping. We also thank the anonymous referees for their helpful comments on the manuscript.

\section{References:-}

1. ANDS, (2011) : Situation économique et sociale du Sénégal en 2011. Rap. tech., 343p.

2. Bousso, T. (1994): Typologie des engins et techniques de pêche artisanale utilises au Sine-Saloum (Sénégal). Doc. Sci., $\mathrm{n}^{\circ} 141$, pp. 111.

3. Charles-Dominique, E. (2003): Engins et techniques de pêche artisanale du Sénégal. 28p.

4. CRODT, (2012): Statistiques de la pêche maritime sénégalaise en 2011. Pêche artisanale, pêche sardinière et pêche thonière. Rapport 2011, Arch. Sci. CRODT, no. 221. 41p.

5. Fall, M., Samba, A. and Laloë, F. (2006): Fishing tactics and strategies in coastal demersal trawling fisheries in Senegal. Aquat. Living Resour., 19: 307-316.

6. Ferraris, J. and Samba, A. (1992): Variabilité de la pêche artisanale et statistique exploratoire. In Laloë F., 1992. (Ed.), Statistique impliquée. Actes du cinquième séminaire informatique de l'ORSTOM (Séminfor 5), Montpellier du 2 au 4 septembre 1991. Editions ORSTOM, Paris, France, pp. 169-189.

7. Forcada, A., Valle, C., Sánchez-Lizaso, J.L., Bayle-Sempere, J.T. and Corsi, F. (2009): Structure and spatiotemporal dynamics of artisanal fisheries around a Mediterranean marine protected area. ICES J. Mar. Sci., 67: 191-203.

8. Fluharty, D. (2011): Decision-Making and Action Taking: Fisheries Management in a Changing Climate, OECD Food, Agriculture and Fisheries Papers, No. 36, OECD Publishing.

9. Jabeur, C., Gobert, B. and Missaoui, H. (2000): Typologie de la flottille de pêche côtière dans le golfe de Gabès (Tunisie). Aquat. Living Resour., 13: 421-428.

10. Kébé, M. (2008): Le secteur des pêches au Sénégal : Tendances, enjeux et orientations politiques. Programme Kurukan Fugan. 26p.

11. Leleu, K., Pelletier, D., Charbonnel, E., Letourneur, Y., Alban, F., Bachet, F. and Boudouresque, C.F. (2014): Métiers, effort and catches of a Mediterranean small-scale coastal fishery: The case of the Côte Bleue Marine Park. Fish. Res., 154: 93-101.

12. Laloë, F. and Samba A. (1990): La pêche artisanale au Sénégal: ressource et stratégies de pêche. Thèse de doctorat Sciences de la vie, Université Orsay-Paris Sud. Paris, France, 395p.

13. Maynou, F., Demestre, M., Sanchez, P. (2003): Analysis of catch per unit effort by multivariate analysis and generalised linear models for deepwater crustacean fisheries off Barcelona (NW Mediterranean). Fish. Res., 65: 257-269.

14. Maynou, F., Recasens, L. and Lombarte, A. (2011): Fishing tactics dynamics of a Mediterranean 560 smallscale coastal fishery. Aquat. Living Resour., 24: 149.

15. Ndour, I., Le Loc'h, F., Kantoussan, J., Thiaw, M., Diadhiou, H.D., Ecoutin, J.M., Tito de Morais, L. and Thiaw, O.T. (2014): Changes in the trophic structure, abundance and species diversity of exploited fish assemblages in the artisanal fisheries of the northern coast, Senegal, West Africa. Afr. J. Mar. Sci., 36(3): 361 368.

16. Pelletier, D. and Ferraris, J. (2000): A multivariate approach for defining fishing tactics from commercial catch and effort data. Can. J. Fish. Aquat. Sci., 57: 51-65.

17. Thioulouse, J. and Dray, S. (2007): Interactive Multivariate Data Analysis in R with the ade4 and ade4TkGUI Packages. J. Stat. Softw., 22(5): 1-14. 